\title{
Compensatory mitigation for injury to a threatened or endangered species: scaling piping plover restoration
}

\author{
Michael Donlan ${ }^{1, *}$, Molly Sperduto $^{2}$, Charlie Hebert ${ }^{3}$ \\ ${ }^{1}$ Industrial Economics, 2067 Massachusetts Avenue, Cambridge, Massachusetts 02140, USA \\ ${ }^{2}$ United States Fish and Wildlife Service, 70 Commercial St, Suite 300, Concord, New Hampshire 03301, USA \\ ${ }^{3}$ United States Fish and Wildlife Service, 911 NE 11th Ave, Portland, Oregon 97232, USA
}

\begin{abstract}
Conducting natural resource damage assessments and adopting compensatory restoration plans for endangered and threatened species have special constraints. These constraints are illustrated by the agency responses to evaluate impacts of the North Cape oil spill on piping plovers Charadrius melodus in Rhode Island, and to establish appropriate compensatory restoration. Adopting a precautionary principle implies that strict adherence to an $\alpha$-value of 0.05 in formal tests for injury on endangered species, where rarity implies low statistical power, would result in overlooking many true impacts. Criteria for concluding that injury took place must nonetheless exist, including (1) existence of a conceptually valid mechanism to link exposure to the stressor and the documented negative responses; (2) field data supporting the existence of the stressor-response link; and (3) sampling designs that consider impacts of potentially confounding factors such as natural temporal change. Choosing restoration options is also challenging for endangered species because ethical considerations and risks associated with some interventions preclude otherwise acceptable actions for common species. For the piping plover, a synthesis of population limitations done for the species recovery plan was used to design compensatory restoration of protection of nesting on newly colonized beaches, an action difficult to scale in advance to match the estimated injury from oil, but adaptively adjustable if monitoring shows a need.
\end{abstract}

KEY WORDS: Restoration - Compensatory mitigation $\cdot$ Habitat protection $\cdot$ Piping plover $\cdot$ Oil spill · Endangered species $\cdot$ Threatened species

\section{INTRODUCTION}

Conservation biologists tend to express a strong preference for preserving or restoring habitat, instead of taking actions designed to benefit particular target species. This attitude is based upon recognition that habitat destruction and degradation are responsible for the majority of losses to the natural biota (Soule 1986). In addition, oil spills and other pollution events frequently affect a broad range of biota present in the area of impact. Actions taken to benefit habitat will contribute to the welfare of several species simultaneously, and not just one. Furthermore, simply enhancing numbers of new recruits of a target species will fail to achieve a sustainable increase in the population if the carrying capacity of the environment required to support them is inadequate (Meffe et al. 1997). Nevertheless, endangered and threatened species represent a special group for which explicit legislation or ethical concerns may often dictate that protection, restoration, and enhancement efforts be focused at the level of the individual species (Peterson et al. 2003, in this Theme Section).

Establishing the scientific basis for supporting restoration of rare and declining species is a challenge for ecologists and conservation biologists because of several constraints. Rarity itself implies low sample 
sizes for most ecological studies, and therefore high uncertainty in estimating abundance or in evaluating the success of alternative intervention options designed to benefit the population. This concern has generated the development of statistical methods explicitly designed to deal with rare species (e.g. Green \& Young 1993, Strayer 1999). Occasionally, research will be done on a more abundant surrogate species (Caro \& O'Doherty 1999), but this approach requires establishing, with confidence, that the factors responsible for the large demographic differences between the conservation target and the surrogate species do not prevent rigorous transfer of results from one to the other (Bevill \& Louda 1999). Of the many causes for rarity, some imply intrinsic incompatibilities between even closely related species (Kunin \& Gaston 1993). Ethically, restoration options that entail risk to the threatened population cannot be justified, thereby closing the door to some actions that may indeed have been beneficial. Ethics further dictate that where data are sparse and uncertainty high, a precautionary approach be taken in evaluating evidence of injury to a threatened or endangered species and in adopting restoration plans to compensate for that injury (Gerber et al. 1999).

In the US, recovery plans for many listed species have been developed and implemented by federal agencies charged with administration of the Endangered Species Act. Such plans are helpful in developing compensatory restoration because they review the causes of population limitation for the target species and identify potential restoration actions.

Here we illustrate how the constraints of rarity and the existence of an established recovery plan affect the process of choosing, scaling, and implementing compensatory restoration through the example of a federally threatened shorebird, the piping plover Charadrius melodus. Known nesting grounds for piping plovers were extensively polluted by the 1996 North Cape oil spill in Rhode Island. This oil spill precipitated studies of the impacts on the Moonstone Beach breeding population of piping plovers, and led to the development of compensatory restoration actions. By describing the process of injury assessment and restoration development, we communicate insights of value to restoration of other threatened or endangered species.

\section{THE BIOLOGY OF PIPING PLOVERS AND RISKS FROM THE OIL SPILL}

The piping plover is a shorebird, once described as common along Atlantic beaches, that became greatly diminished in abundance by 1900 through hunting and egg gathering (Haig \& Oring 1987). Numbers partially rebounded after passage of the Migratory Bird Treaty Act in 1918, but declined again after World War II with the increase in coastal development and recreation (Raithel 1984). Rhode Island and other New England states provide summer nesting habitat on coastal beaches. Birds arrive in Rhode Island in late March or early April. By late April, pairs are established and nest construction has begun (MacIvor 1990, Keane 2002). Nests are constructed above the high-tide line on coastal beaches, with preferences exhibited for wide beach, sand spits, overwash areas, and other disturbed habitat with sparse vegetation and proximity to protected, moist foraging habitats (Burger 1987, Elias et al. 2000, Keane 2002). Egg laying and chick rearing typically take place from May through June, with most chicks fledging in late June and July. Chicks are precocial but cannot fly for their first month after hatching. Chicks spend a high proportion of their time feeding, leading to a tripling of weight in their first $2 \mathrm{wk}$. Any that fail to achieve at least $60 \%$ of adult weight by Day 12 are unlikely to survive (Cairns 1977). Piping plovers feed on invertebrates from intertidal pools, wrack lines on beaches, sand and mud flats, overwash areas, and shorelines of coastal ponds, lagoons, and salt marshes (Goldin 1993, US Fish and Wildlife Service 1996).

On 19 January 1996, the barge North Cape grounded on the Rhode Island shoreline, causing a subsequent oil spill. A nearby beach, Moonstone Beach, known to provide consistently used nesting and brood habitat for the piping plover, was oiled. Because this oiling occurred well before the seasonal return of breeding plovers, acute mortality from oiling was not an issue. However, the loss of invertebrate prey, with subsequent increased foraging costs and risks, and consequent reductions in energy intake, growth, and survival of chicks, represented a potential injury to the local population. To evaluate this hypothesis, studies were undertaken to (1) identify any spill-related impacts on plover prey abundance at impact and reference beaches, and (2) document piping plover behavior and productivity at impact and reference beaches during the breeding season following the spill, and compare this information to historical data.

\section{IMPACT OF THE OIL SPILL ON PIPING PLOVERS}

Prey abundance at oiled and reference beaches. Piping plovers consume infaunal, epifaunal and flying prey. To measure prey abundance in the wrack and dune foraging habitats, standard pitfall traps were utilized at the oiled (Moonstone Beach), and a nearby unoiled (East Beach), plover nesting areas (Gould 1996). This methodology targeted surface crawling invertebrates, including amphipods, because they are 
an important component of piping plover diets (Shaffer \& Laporte 1994, Staine \& Burger 1994). While the wrack line generally comprises a small amount of barrier beach habitat, studies have shown it to be a very important and preferred foraging habitat, where bayside intertidal or ephemeral pool habitats are not available (Hoopes et al. 1989, Goldin 1993, Elias et al. 2000). Ten 1 gallon (3.8 1) pitfall traps were established at each beach, 5 along the wrack and 5 along the dune. Wrack samples were collected seaward of plover nests, $100 \mathrm{ft}(30 \mathrm{~m})$ away (along the water line) to minimize disturbance to nest sites. Traps were set on 29 May 1996 and collected approximately $24 \mathrm{~h}$ later. Trap contents were preserved and tabulated using standard laboratory procedures. The dominant macroscopic organism by weight and volume in the wrack areas of both beaches was the amphipod Talorchestia longicornis. Mean volume and wet weight of the amphipods at the oiled and unoiled beach wrack were significantly different based on $t$-test results (volume: $3.58 \pm 1.95 \mathrm{ml}$ $[$ mean $\pm \mathrm{SD}$ ] vs $20.28 \pm 9.94 \mathrm{ml}[$ mean $\pm \mathrm{SD}], \alpha=0.01$, respectively; weight $1.70 \pm 1.06 \mathrm{mg}[$ mean $\pm \mathrm{SD}$ ] vs $13.24 \pm 7.23 \mathrm{mg}$ [mean $\pm \mathrm{SD}$ ], $\alpha=0.01$, respectively)

To measure prey abundance in the intertidal zone, invertebrates were sampled on 27 and 28 June 1996 at Moonstone Beach and at a different reference beach (Goosewing Beach) using cores $(10 \mathrm{~cm}$ in diameter and $10 \mathrm{~cm}$ deep) (SAIC 1996). Samples were collected from 10 stations systematically placed across the face of each beach. Samples were sieved with 2.0 and $1.0 \mathrm{~mm}$ mesh screens. Sample material was preserved with a solution of buffered formalin and rose Bengal and then identified and enumerated. While average invertebrate abundances (based on number of organisms) at Moonstone and Goosewing Beaches were not significantly different $(\alpha=0.05)$, species composition varied between the beach intertidal zones (SAIC 1996). Only 2 Amphiporeia virginiana were found at Moonstone Beach sample sites, compared to 456 at Goosewing Beach sites (the most common invertebrate, by more than 1 order of magnitude). The predominant organism (in terms of numeric abundance) at Moonstone Beach was Marionina subtarranea. According to the SAIC authors, 'the virtual absence of $A$. virginiana from Moonstone Beach is consistent with the hypothesis that this habitat was exposed to oil. It is well known that amphipods are the first group of organisms to disappear and one of the last to recolonize habitats exposed to oil spills (e.g. Dauvin 1979, Sanders et al. 1980)' (SAIC 1996, p. 3). These data suggest that the piping plovers' food supply may have been reduced due to the spill.

Reproductive success at the oiled beach. As a means of testing the impacts of oiling Moonstone Beach, piping plover nesting, chick rearing, and chick foraging activities were monitored during 1996 at the oiled beach and compared to similar data from previous years. Management activities undertaken in 1996 for plover protection included all those conducted annually since 1992: erection of symbolic fencing (a cord of yellow rope attached to posts anchored in the beach) to warn intruders, predator controls, nest exclosures, and beach-user educational efforts. One additional management activity (trapping of predators) was added in 1995 and repeated in 1996. A local trapper was contracted to trap along the barrier beach, and removed 1 coyote and 2 mink from the area in 1996. Predator removal data from 1995 are unavailable, although the level of trapping effort was believed to be similar in both years.

Piping plover productivity proved lower in 1996 than in the previous year, and differences in chick foraging behavior may explain the lower productivity. As shown in Table 1, in 1996 an average of 1.0 fledgling was produced per nesting pair, as compared to 1.6 in the previous year, a reduction of $37 \%$ (Casey 1996). Plovers reuse nesting sites with a high degree of faithfulness over years (MacIvor et al. 1987, Strauss 1990), and the nesting in 1996 was indeed within the same general area as in 1994 and 1995. Nevertheless, the average daily distance traveled for foraging by chicks in 1996 was substantially greater than in 1994 and 1995 (Casey 1996). Quantitative daily distance data are available for multiple years at nests in 4 locations. Average daily distances traveled by chicks nesting in the 1st location were 290.5 (1996) vs $128.9 \mathrm{~m} \mathrm{(1994);} 124.1$ (1996) vs $44.5 \mathrm{~m}$ (1994) in the 2nd location; 87.2 (1996) vs $14.0 \mathrm{~m}$ (1995) in the 3rd location; and 39.6 (1996), 21.0 (1995) vs $23.4 \mathrm{~m}$ (1994) in the 4 th location.

Thus, the productivity decline from 1995 to 1996 could be attributed to the oiling of the beach reducing invertebrate prey in the wrack (preferred foraging habitat) and intertidal habitat, causing plovers to travel longer distances and expend more energy during foraging, with likely costs of slower growth and perhaps higher mortality. Although combining the information on oiling intensity, prey abundances in the wrack, foraging behavior, and productivity provides a consistent mechanistic indication of injury to plover populations from the oil spill, one additional anomaly in the productivity patterns over the years needs mention. The 1.0 fledgling per nesting pair in 1996 exceeded or equaled the documented productivity on this beach from 1991 through 1994 (Casey 1996). To conclude that the drop from 1995 to 1996 represents an indication of a spill impact requires the additional assumption that the predator trapping initiated in 1995 and continued in 1996 was indeed successful in setting a new baseline productivity of 1.6 fledgling per nesting pair in 1995. This is a reasonable, but untested, assumption. 
Table 1. Charadrius melodus. Results of piping plover reproductive success at reference and impact area beaches. Source of data: McGourty (1996), Table 2 and Casey (1996, Appendix E)

\begin{tabular}{|c|c|c|c|c|c|c|c|c|c|}
\hline Year & Sites & Pairs & Nests & Eggs & Hatched & $\begin{array}{c}\text { Hatched } \\
(\%)\end{array}$ & $\begin{array}{c}\text { Fledged } \\
(\%)\end{array}$ & $\begin{array}{l}\text { Fledged } \\
\text { per pair }\end{array}$ & Fledglings \\
\hline \multicolumn{10}{|c|}{ Reference area beaches } \\
\hline 1996 & 6 & 20 & 22 & 87 & 75 & 86 & 42 & 56 & 2.1 \\
\hline 1995 & 4 & 13 & 18 & 63 & 46 & 73 & 24 & 52 & 1.9 \\
\hline 1994 & 4 & 9 & 10 & 39 & 31 & 80 & 22 & 71 & 2.4 \\
\hline 1993 & 3 & 9 & 11 & 45 & 32 & 71 & 23 & 72 & 2.6 \\
\hline 1992 & 2 & 5 & 6 & 23 & 15 & 65 & 12 & 80 & 2.4 \\
\hline \multicolumn{10}{|c|}{ Impact area beach } \\
\hline 1996 & 1 & 9 & 16 & 53 & 22 & 42 & 9 & 41 & 1.0 \\
\hline 1995 & 1 & 9 & 9 & 35 & 31 & 89 & 14 & 45 & 1.6 \\
\hline 1994 & 1 & 8 & 9 & 33 & 17 & 52 & 8 & 47 & 1.0 \\
\hline 1993 & 1 & 8 & 10 & 38 & 33 & 87 & 7 & 21 & 0.9 \\
\hline 1992 & 1 & 6 & 6 & 19 & 7 & 37 & 4 & 57 & 0.7 \\
\hline
\end{tabular}

Reproductive success at nearby reference beaches. To test whether the 1996 change in piping plover productivity on the oiled Moonstone Beach was simply a consequence of natural year-to-year dynamics in this general geographic area, piping plover nesting and foraging were also monitored in 1996 at 6 reference beaches in southern Rhode Island (McGourty 1996), and comparisons made to historical data available from 4 of those locations (Table 1). The reference beaches are similarly oriented (facing Block Island Sound in a generally SSE direction), within approximately $25 \mathrm{~km}$ of the oiled beach, and so likely comparably exposed to storms and broader-scale environmental conditions that could affect productivity. Sparsely vegetated beach face, sand spit and/or overwash areas preferred by the piping plover were available, and plovers successfully nested at oiled and reference beaches (Casey 1996, McGourty 1996). Predation and disturbance by humans and pets are important threats to plover populations (US Fish and Wildlife Service 1996). Reference and oiled beaches were subjected to similar management protections (generally including the use of symbolic fencing, predator exclosures and volunteers to help monitor nests, educate the public and discourage disturbance of plover nesting areas), and management actions taken at reference beaches in 1996 were similar to those applied in previous years.

Records were kept on numbers of nesting pairs, hatching success, chick mortality, productivity, nest failure/abandonment, territory size, and chick movement. The numbers of fledglings per plover pair increased on average at reference beaches from 1.9 in 1995 to 2.1 in 1996 (an increase of approximately 10\%) (Table 1). Compared with the $37 \%$ decrease observed at the oiled beach in that same year, plover reproductive success on reference beaches did not show a decline from 1995 to 1996. This further supports the inference of spill-induced impacts on Moonstone Beach. However, average productivity per nesting pair at the reference beaches in 1995 (1.9) and 1996 (2.1) was less than the range of 2.4 to 2.6 fledglings produced on average in the 1992 to 1994 period. Thus, the 1996 productivity at these beaches was compared to a 'base' year (1995) with relatively low productivity levels.

Injury quantification. With only 9 nesting pairs at the impact beach, factors unrelated to the spill cannot be ruled out as a cause of the observed productivity decline using traditional standards of statistical significance. For example, variation in physical environmental factors could produce a change in productivity of $37 \%$ without any impact from oil. Piping plovers suffer losses of fledglings and reductions in productivity from several factors that were not, and cannot, all be monitored, such as pedestrian disruptions (Burger 1991), loose dogs (Cairns \& McLaren 1980), predation (Burger 1987, MacIvor 1990, Elias-Gerken \& Fraser 1994), and storms. However, analysis of temporal trends in productivity at oiled and reference beaches and documented differences in plover prey and changes in foraging behavior, combined with a synthesis of the literature on processes that affect productivity of piping plovers, lend support to the case for spill-related injury to Moonstone Beach plovers. Adoption of a precautionary approach for threatened and endangered species (e.g. Gerber et al. 1999) dictates that compensatory restoration be done: conceptually valid mechanisms can explain impacts to the population; field data establish a credible link between the hypothesized source of harm and the impact; and empirical field observations comparing temporal trends at oiled and reference areas reduce (but do not eliminate) the likelihood that any observed changes were due to chance or larger-scale factors affecting multiple nesting beaches. 
To estimate the approximate magnitude of injury to this plover population, we adopted a simplified approach. We assumed that in the absence of the spill, productivity in 1996 would have equaled productivity in 1995. Then, lost piping plover productivity in 1996 can be approximated by:

(1995 productivity -1996 productivity) $\times$ number of plover pairs in $1996=$ lost chicks $(1.56$ chicks per pair 1.00 chicks per pair $) \times 9$ pairs $=5.0$ fledged chicks

To this loss in 1996 chick production, we must add impacts to future productivity, assuming that plovers are not limited by available overwintering, foraging, or nesting habitat, but rather by numbers of recruits surviving to enter the breeding population. Using a chick over-winter survival rate of $48 \%$ (Melvin \& Gibbs 1994), 2.4 of those 5 missing chicks would have been expected to survive the winter and return to breed the following year. Assuming a 1997 productivity equal to that of 1995 (1.56 chicks per pair), the chicks lost because the spill would be expected to have produced 1 to 2 (1.87) fledglings of their own in 1997. This process could be extended to several generations. However, this more elaborate calculation seemed unjustified for 2 reasons. First, we do not know for certain that piping plovers are limited by recruitment to the breeding population instead of habitat (US Fish and Wildlife Service 1996). Second, if a restoration action could be designed to enhance the piping plover numbers by at least 5 chicks, then their subsequent contributions to the future generations will be expected to match what would have been provided by the lost chicks. This approach avoids the need to quantify demographic consequences of chick loss, although it does ignore the time lag between injury and restoration by failing to apply a discount factor. Such precision was judged unnecessary, given the uncertainty in quantifying the compensatory restoration action selected.

\section{RESTORATION OPTIONS AND SCALING}

Identifying compensatory restoration options for a threatened or endangered species requires the same in-depth review of demographic limitations to population growth, as is required for developing restoration plans for any species. This task is made easier for those federally listed species in the US that have recovery plans. The piping plover recovery plan (US Fish and Wildlife Service 1996) served to guide compensatory restoration planning after the North Cape oil spill. A careful review of this piping plover recovery plan, and the management actions already in place in Rhode Island, led to the selection of an unimplemented restoration action to serve as compensation for the likely loss of 5 or more plovers from the oil spill. The trustees of public trust resources decided upon a compensatory restoration action that involved identifying potential breeding beaches in the vicinity of the spill area that were newly colonized by young adults, which exhibit much greater propensity than experienced breeders to colonize new breeding sites (Wilcox 1959). By immediately extending management protections to them, similar to the management already in place at historic breeding beaches, productivity could be enhanced. This option is not novel. It was used to compensate for plover losses after a previous oil spill in Rhode Island, the World Prodigy in 1989. Consequently, the documented success in fledging of additional chicks from that program could be used to scale the area of beach surveyed and the amount of protection required to compensate for the 5 or more chicks lost to this North Cape spill in 1996.

Table 2 provides productivity data at the 4 beaches affected by the World Prodigy piping plover restoration (Napatree Point, Ninigret east beach, Quononchontaug, and Watch Hill east beach). Monetary compensation received as a result of the World Prodigy spill funded management protection efforts at these beaches in 1992,

Table 2. Charadrius melodus. Comparison of piping plover reproductive success at beaches affected by the 1992 to 1994 World Prodigy restoration project before and during project implementation. na: not available. Source of data: Suzanne Paton, RI National Wildlife Refuge Complex, pers. comm.

\begin{tabular}{|c|c|c|c|c|c|c|c|c|}
\hline \multirow[t]{2}{*}{ Year } & \multicolumn{2}{|c|}{ Napatree Point } & \multicolumn{2}{|c|}{ Ninigret CA (east beach) } & \multicolumn{2}{|c|}{ Quononchontaug } & \multicolumn{2}{|c|}{ EB Watch Hill (east beach) } \\
\hline & Pairs & Fledges & Pairs & Fledges & Pairs & Fledges & Pairs & Fledges \\
\hline 1994 & 2 & 0 & 2 & 6 & 1 & 3 & 4 & 13 \\
\hline 1993 & 4 & 4 & 1 & 3 & 0 & 0 & 4 & 16 \\
\hline 1992 & 1 & 0 & 0 & 0 & 1 & 1 & 4 & 11 \\
\hline Mean (1992-1994) & 2.33 & 1.33 & 1.0 & 3.0 & 1 & 1.33 & 4 & 13.33 \\
\hline 1991 & 3 & 0 & 1 & 0 & 1 & 0 & 4 & 2 \\
\hline 1990 & 2 & 0 & na & na & na & na & 4 & 0 \\
\hline 1989 & 1 & 0 & na & na & na & na & 4 & 2 \\
\hline Mean (1989-1991) & 2.0 & 0 & na & na & na & na & 4 & 1.33 \\
\hline
\end{tabular}


1993 and part of 1994. Productivity data were available for $3 \mathrm{yr}$ prior to implementation of the World Prodigy restoration at Napatree Point and EB Watch Hill. As shown in Table 2, productivity increased substantially at EB Watch Hill during 1992 to 1994, despite no change in the number of nesting pairs (4). At least 11 chicks fledged during each year that protection was in place; in the 3 yr prior to protection, no more than 2 chicks fledged in any year. However, at Napatree Point, no fledglings were produced during 2 of the 3 yr that World Prodigyfunded protections were in place. Such comparisons at the other 2 beaches are difficult to make given the availability of only 1 yr of pre-restoration productivity data. Overall, precise quantification of restoration benefits attributable to the World Prodigy is not possible, due to the many factors that affect fledgling survival and the small number of plover pairs at these beaches. Nevertheless, available data suggest that a World Prodigyscale restoration project is capable of producing several fledglings per year, although inter-beach and inter-year variability is likely to be high.

\section{DISCUSSION}

The evaluation of impacts of the North Cape oil spill on the piping plover population of Rhode Island beaches, and the process of deciding upon a restoration option and scaling it to the injury, provide some generic guidance for endangered and threatened species. Here the concern for Type II error of not detecting a true impact of the spill (Fairweather 1991) was sufficient to lead to a conclusion of likely impact of the oil spill, despite the lack of evidence that would meet the standard test of statistical significance at an $\alpha$-value of 0.05. Specialized statistical methods (e.g. Green \& Young 1993, Strayer 1999) and other approaches (e.g. Caro \& O'Doherty 1999) have been developed to establish a scientific basis for restoration decisionmaking with rare species. The most rigorous analytic approach possible must be implemented; in circumstances where sufficient data simply cannot be obtained, cautious application of statistical hypothesis testing seems an appropriate response to the special importance that endangered and threatened species have, and an appropriate application of the precautionary principle (Peterman \& M'Gonigle 1992, Gerber et al. 1999). With both intrinsic difficulties in detecting effects on small and rare populations (Green \& Young 1993) and also high societal importance of any negative impacts that do exist, managerial inaction based on absence of statistical significance may not be appropriate. The piping plover example described here provides a reasonable set of minimum criteria for deciding that evidence is sufficient to trigger compensatory res- toration actions for threatened and endangered species in the absence of sufficient data for statistical evaluation: a conceptually valid mechanism of harm should exist, and field data should link the stressor to the response(s) and provide evidence of a negative impact based on a reasonable sampling design including, to the degree possible, temporal and reference-area comparisons.

Our description of the decision-making process of development of a compensatory restoration program also has broad generic application to endangered, threatened, or simply rare species of concern. The existence of carefully considered recovery plans for federally listed species in the US and species of concern in other countries gives a jump-start to planning for compensatory restoration after any environmental incident. However, development of a viable restoration option may be challenging in cases where significant actions have already been taken by managers of endangered species. Furthermore, the ethical and biological constraints in manipulation of endangered species preclude selection of some reasonable restoration actions that involve unacceptable risks. Application of the concept of compensatory restoration to endangered species will also commonly require relaxation of the quantification standards that are typically applied to scale restoration in order to provide a quantitative match to the injury. Instead, subsequent monitoring of the effectiveness of restoration and adaptive adjustment of the restoration program, if necessary, can serve to insure the conservation mandate of the trustees of natural resources.

Acknowledgements. Support for this work was provided by the NOAA (National Atmospheric and Oceanographic Administration) Damage Assessment Center and the US Fish and Wildlife Service. C. H. Peterson provided editorial guidance. Input from L. D'Anna, L. von Oettingen and A. Hecht was helpful.

\section{LITERATURE CITED}

Bevill RL, Louda SM (1999) Comparisons of related rare and common species in the study of plant rarity. Conserv Biol 13:493-498

Burger J (1987) Physical and social determinants of nest selection in piping plover in New Jersey. Condor 98: 811-818

Burger J (1991) Foraging behavior and the effect of human disturbance on the piping plover (Charadrius melodus). J Coast Res 7:39-52

Cairns WE (1977) Breeding biology and behaviour of the piping plover Charadrius melodus in southern Nova Scotia. MSc thesis, Dalhousie University, Halifax

Cairns WE, McLaren IA (1980) Status of the piping plover on the east coast of North America. Am Birds 34:206-208

Caro TM, O'Doherty G (1999) On the use of surrogate species in conservation biology. Conserv Biol 13:805-814 
Casey JK (1996) Assessment of the North Cape oil spill impacts to the 1996 piping plover breeding season at Trustom Pond NWR. US Fish and Wildlife Service Report, Ninigret National Wildlife Refuge, Charlestown, RI

Dauvin JC (1979) Impact des hydrocarbures de l'Amoco Cadiz sur le peuplement infralittoral des sables fins de la Pierre Noire (Baie de Morlaix). J Rech Oceanogr 4:28-29

Elias SP, Fraser JD, Buckley PA (2000) Piping plover brood foraging ecology on New York barrier islands. Wildl Manag 64:346-354

Elias-Gerken SP, Fraser JD (1994) Piping plover foraging ecology on Pike's Beach, Southampton, New York. Report to US Fish and Wildlife Service. USFWS, Sudbury, MA

Fairweather PG (1991) Statistical power and design requirements for environmental monitoring. Aust J Mar Freshw Res 42:555-567

Gerber LR, DeMaster DP, Karieva PM (1999) Gray whales and the value of monitoring data in implementing the US Endangered Species Act. Conserv Biol 13:1215-1219

Goldin MR (1993) Piping plover (Charadrius melodus) management, reproductive ecology, and chick behavior at Goosewing and Briggs Beaches, Little Compton, Rhode Island, 1993. The Nature Conservancy, Providence, RI

Gould R (1996) A comparison of invertebrate pit-trap samples from Trustom Pond and East Beaches, Rhode Island, USA following an oil spill. Report to US Fish and Wildlife Service, Concord, NH

Green RH, Young RC (1993) Sampling to detect rare species. Ecol Appl 3:351-356

Haig SM, Oring LW (1987) The piping plover. In: DiSilvestro $\mathrm{R}$ (ed) Audubon Wildlife Report. National Audubon Society Academic Press, New York, p 503-519

Hoopes EM, Griffin CR, Melvin SM (1989) Effects of human recreation on piping plover foraging ecology and chick survival at Ninigret National Wildlife Refuge. Report to US Fish and Wildlife Service, Newton Corner, MA

Keane SE (2002) Effects of herring gulls and great blackbacked gulls on breeding piping plovers, South Monomoy Island, Massachusetts. MSc thesis, Virginia Tech, Blacksburg, VA

Kunin WE, Gaston KJ (1993) The biology of rarity: pattern causes, and consequences. Trends Ecol Evol 8:298-301

MacIvor LH (1990) Population dynamics, breeding ecology, and management of piping plovers on outer Cape Cod, Massachusetts. MSc thesis, University of Massachusetts, Amherst, VA

MacIvor LH, Griffin CR, Melvin SM (1987) Management, habitat selection, and population dynamics of piping

Editorial responsibility: Charles Peterson (Contributing Editor), Morehead City, North Carolina, USA plovers on outer Cape Cod, Massachusetts: 1985-1987. Report to the National Park Service, Cape Cod National Seashore, South Wellfleet, MA

McGourty E (1996) Rhode Island piping plover restoration project 1996. Ninigret National Wildlife Refuge, Charlestown, RI

Meffe GK, Carroll GR (1997) Principles of conservation biology, 2nd edn. Sinauer, Sunderland, MA

Melvin SM, Gibbs JP (1994) Viability analysis for the Atlantic coast population of piping plovers. Report to US Fish and Wildlife Service, Sudbury, MA

Peterman RM, M'Gonigle M (1992) Statistical power analysis and the precautionary principle. Mar Pollut Bull 24: 231-234

Peterson CH, Kneib RT, Manen C-A (2003) Scaling restoration actions in the marine environment to meet quantitative targets of enhanced ecosystem services. Mar Ecol Prog Ser 264:173-175 (in this Theme Section)

Raithel C (1984) The piping plover in Rhode Island. Rhode Island Natural Heritage Program, Providence, RI

SAIC (Science Applications International Corp) (1996) Potential impact of the North Cape Oil Spill on piping plover and shorebird prey species in intertidal and breach/pond shore habitats: interpretation of benthic data. Report to Beak Consultants, Kirkland, WA

Sanders HL, Grassle JF, Hampson GR, Morse LS, GarnerPrice S, Jones CC (1980) Anatomy of an oil spill: long-term effects from the grounding of the barge Florida off West Falmouth, Massachusetts. J Mar Res 38:265-380

Shaffer F, LaPorte P (1994) Diet of piping plovers on the Magdalen Island, Quebec. Wilson Bull 106:531-536

Soule M (1986) Conservation biology. Sinauer, Sunderland, MA

Staine KJ, Burger J (1994) Nocturnal foraging behavior of breeding piping plovers (Charadrius melodus) in New Jersey. Auk 111:579-587

Strauss E (1990) Reproductive success, life history patterns, and behavioral variation in a population of piping plovers subjected to human disturbance (1982-1989). PhD thesis, Tufts University, Medford, MA

Strayer DL (1999) Statistical power of presence-absence data to detect population declines. Conserv Biol 13: 1034-1038

US Fish and Wildlife Service (1996) Piping plover (Charadrius melodus) Atlantic coast population: revised recovery plan. US Fish and Wildlife Service, Hadley, MA

Wilcox L (1959) A twenty year banding study of the piping plover. Auk 76:129-152

Submitted: July 25, 2003; Accepted: October 30, 2003

Proofs received from author(s): November 27, 2003 